\title{
Valg i Aserbajdsjan - ad velkendte veje
}

\section{Jesper Weng Rasmussen}

\section{Det netop afholdte valg i den transkaukasiske republik resulterede officielt i en overvældende sejr til det regerende parti, mens oppositionen endnu engang vandt meget få pladser}

Valget var som tidligere valg kendetegnet ved en valgkamp præget af det siddende styres dominans både over medier og lokalforvaltninger kombineret med et forsøg på demokratisk legitimation over for især det vestlige udland.

Der har således både været arrestationer af medlemmer af ungdomsorganisationer, som de der prægede omvæltningerne i nabolandet Georgien og i Ukraine, anholdelse af ministre for angivelige kupplaner samt klar kontrol over medierne fra myndighedernes side. Det har dog samtidig været tilladt mange partier og kandidater at stille op, ligesom oppositionen er blevet tildelt (begrænset) tid på offentligt tv, og der har også været mulighed for at afholde demonstrationer - sidstnæunte dog på decentrale steder og ofte med kraftigt politiopbud og -indblanding.
På trods af internationale observatørers klare kritik af selve valghandlingen og oppositionens fredelige demonstrationer imod det officielle valgresultat er der i skrivende stund ikke meget, der tyder på endnu en regimeomvæltning i en tidligere sovjetrepublik, som det har været tilfældet i Georgien, Ukraine og Kirgisistan. Oppositionen har dog afholdt den første massedemonstration i håbet om at starte en bølge af protester, der vil resultere i en regimeomvæltning.

Aserbajdsjan opnåede selvstændighed i 1991 i kølvandet på Sovjetunionens opløsning.

Selvstændigheden og de første nyere forsøg på demokrati, efter i godt 70 år at have været en del af Sovjetunionen, forekom midt i en krig med nabolandet Armenien over den aserbajdsjanske enklave Nagorno- 
Karabakh, der primært var beboet af armeniere.

Den aserbajdsjanske Folkefront, der kæmpede for aserbajdsjansk selvstændighed havde ud over selvstændighed og demokrati som hovedmål at bekæmpe den primært armensk-beboede enklave NagornoKarabakhs løsrivelse fra Aserbajdsjan. I 1992 kom lederen af den aserbajdsjanske folkefront - Abulfaz Elchibey - til magten ved et valg, der er det tætteste på et frit og retfærdigt valg i Aserbajdsjans historie, selvom det ikke levede op til internationale standarder.

Inden da havde den tidligere førstesekretær for det aserbajdsjanske kommunistparti - Ayaz Mutalibov - vundet det første præsidentvalg i det selvstændige Aserbajdsjan - et valg, der mindede om de valg, der blev afholdt i sovjetperioden uden reelle modkandidater og en stærkt censureret presse.

Abulfaz Elchibeys præsidentperiode blev præget af kaos med krigen mod Armenien, der eskalerede, samt interne stridigheder med repræsentanterne for det gamle kommunistiske regime. Sidstnævnte dominerede stadig parlamentet og sad på vigtige poster i centraladministrationen og lokalforvaltningerne.

Den kaotiske situation blev udnyttet af den tidligere førstesekretær for det aserbajdsjanske kommunistparti og medlem af det centrale Politburo i Moskva, Heidar Aliyev, til at overtage magten via udemokratiske metoder. Heidar Aliyev sørgede for stabilitet, men samtidig også for en tilbagegang til kendte autoritære styreformer, der mindede om tiden under kommunistisk styre. Således sørgede Aliyev især via Aserbajdsjans indmelding i SNG og dermed en tilnærmelse til Rusland for, at der blev indgået våbenhvile med Armenien i 1994. Våbenhvilen betød en de-facto armensk kontrol over Nagorno-Karabakh såvel som syv omkringliggende aserbajdsjanske distrikter. Der er endnu ikke fundet en permanent fredsaftale og gentagne opinionsundersøgelser viser, at en stor del af den aserbajdsjanske befolkning støtter en militær løsning på konflikten.

I 1994 blev der ligeledes indgået en aftale med vestlige firmaer om udvikling af den aserbajdsjanske olieindustri og dermed sikret nødvendige investeringer. Heidar Aliyev sikrede sig samtidig kontrol over det politiske system via et hurtigt præsidentvalg efter magtovertagelsen samt det første parlamentsvalg i det selvstændige Aserbajdsjan i 1995. Begge valg blev af internationale observatører stærkt kritiseret for ikke at leve op til internationale demokratiske standarder.

Heidar Aliyev sikrede således den nødvendige stabilitet, mens dele af især den ældre del af befolkningen i Aserbajdsjan stadig forbinder demokrati med ustabilitet, hvilket det siddende styre ikke forsømmer at understrege.

Der har således siden Heidar Ali- 
yevs magtovertagelse - eller for den sags skyld inden da - ikke været en tradition for demokratiske valg, og få iagttagere forventede da også et frit og demokratisk valg ved det netop overståede parlamentsvalg. Der har derimod været større spænding om, hvorvidt den aserbajdsjanske opposition ville kunne formå at mobilisere befolkningen til protester og eventuelt fortsætte bølgen af regimeomvæltninger i de tidligere sovjetrepublikker efter begivenhederne i Georgien, Ukraine og Kirgisistan.

\section{Klanernes betydning}

Der har stået en del på spil ved valget, hvilket har været med til at trække fronterne skarpt op. Således blev det ambitiøse pipeline-projekt (forkortet BTC), der skal forbinde den aserbajdsjanske hovedstad, Baku, og dermed oliereserverne i det Kaspiske Hav med den tyrkiske havneby Ceyhan gennem den georgiske hovedstad Tbilisi, i maj 2005 indviet og forventes inden for få måneder at resultere i den første olieleverance fra Ceyhan.

Dette milliardprojekt med stærke vestlige interesser - pipelinen forventes at mindske afhængigheden af olie fra Mellemøsten - såvel som de forventede rige olieforekomster i den aserbajdsjanske del af det Kaspiske Hav, gør de fremtidige økonomiske udsigter for Aserbajdsjan positive.

Der er i Aserbajdsjan en dyb historisk tradition for klanloyalitet, hvil- ket har gjort det svært at opbygge en nationalstat med loyalitet mod fællesskabet. Klandominansen betyder, at den regerende klan sørger for egne medlemmers velstand, mens andre klaner holdes udenfor. Denne tradition kombineret med en udbredt korruption (Aserbajdsjan er på en delt 137. plads ud af 158 lande på Transparancy Internationals netop offentliggjorte Corruption Perception Index for 2005) øger vigtigheden af at sidde på magten for at få del i velstanden.

Mange er samtidig økonomisk afhængige af, at det siddende styre fortsætter, da det er en betingelse for at beholde deres job, hvilket får eksempelvis lokale guvernører og sågar skoleinspektører til på forskellige niveauer at gøre alt for at sikre YAP-loyale kandidater i at vinde. De fleste politiske partier ses derfor også primært som varetagere af diverse klaninteresser. Således repræsenterer det regerende parti YAP da også den meget magtfulde Nakhichevan-klan, der stammer fra den autonome republik af samme navn.

Valgkampen har generelt været kendetegnet ved en mere aktiv og delvis mere samlet opposition, end det har været tilfældet ved tidligere valg i Aserbajdsjan. Dette kan muligvis skyldes inspirationen fra regimeomvæltningerne i Georgien, Ukraine og Kirgisistan.

Der blev således ud af de mange oppositionspartier - der tidligere som følge af både personspørgsmål 
såvel som divergerende klaninteresser har været splittet - dannet to større valgforbund, hvor man internt undgik at opstille konkurrerende kandidater i hver af de 125 enkeltmandskredse. Den mest betydningsfulde oppositionsblok i valgkampen var Azadlyg (Frihed), der bestod af de tre største oppositionspartier Musavat (Lighed), Aserbajdsjans Demokratiske Parti samt Den Aserbajdsjanske Folkefront.

Især dette valgforbund organiserede demonstrationer mod det nuværende styre og trodsede myndighederne - især de lokale myndigheder i Baku - der forsøgte at forbyde demonstrationer i det centrale Baku og henviste oppositionen til mere decentrale områder, hvilket resulterede i flere voldelige sammenst $\varnothing \mathrm{d}$ mellem demonstranter og politi.

Som ved tidligere valgkampe var indholdet i oppositionens valgkamp i høj grad præget af kravet om demokratiske valg og beskyldninger om det siddende styres manglende demokratiske indstilling og kun i meget ringe grad af fremlæggelse af egne fremtidsmål og sammenhængende valgprogrammer.

En undtagelse var dog valgforbundet YeS (Yeni Sisayet - Ny Politik), der fremlagde et længere, uddybet valgprogram.

En markant begivenhed for oppositionen - såvel som for styret på grund af dets følger - var den tidligere parlamentsformand Rasul Guliyevs forsøg på at returnere til Aser- bajdsjan, efter at have været i mere eller mindre frivilligt asyl i USA siden 1996.

Rasul Guliyev var tidligere allieret med Heidar Aliyev, men ragede uklar med den daværende præsident formodentlig grundet uenighed om sidstnævntes søn Ilham Aliyevs fremtidige rolle i aserbajdsjansk politik. Ilham Aliyev afløste i 2003 sin far på præsidentposten i et ligeledes stærkt kritiseret valg. Rasul Guliyev er formand for Aserbajdsjans Demokratiske Parti og var på vej til Baku den 17. oktober, men blev ved en mellemlanding i den ukrainske by Simferopol tilbageholdt af de ukrainske myndigheder. Det skete med henvisning til den arrestordre Interpol har udsendt efter begæring af de aserbajdsjanske myndigheder, der har anklaget Guliyev for massiv korruption i begyndelsen af 1990'erne, hvor han var leder af det største olieraffinaderi i landet.

Det er uklart, hvorvidt Guliyev selv fortrød sit forehavende eller blev nægtet indrejse i Aserbajdsjan. Myndighedernes forberedelse på Guliyevs ankomst viser, at han er en af de mest magtfulde oppositionspolitikere og en af dem, det siddende styre frygter mest. Der var således et massivt politiopbud omkring Bakus lufthavn, og såvel oppositionstilhængere som vestlige valgobservatører og diplomater blev forment adgang til lufthavnen for at forhindre et muligt triumftog for den hjemvendte oppositionspolitiker. 
Således er den tidligere parlamentsformand en trussel mod det siddende styre, eftersom han angiveligt råder over betydelige økonomiske midler til at føre valgkamp samt repræsenterer den næstmest magtfulde klan i Aserbajdsjan, der ligeledes stammer fra Nakhichevan.

\section{Splittelse i eliten}

Guliyevs mislykkede tilbagevenden resulterede i et markant opgør inden for den siddende elite, der viste et af sine sjældne tegn på splittelse. Denne splittelse har der længe været gisnet om, men hidtil har der manglet tydelige tegn herpå.

I dagene efter det mislykkede forsøg på at returnere til Aserbajdsjan blev flere fremtrædende medlemmer af den politiske og økonomiske elite arresteret og anklaget for planlægning af en regimeomvæltning. Blandt de anholdte var to ministre sundhedsminister Ali Insanov samt minister for økonomisk udvikling Farhad Aliyev (ingen relation til præsident Ilham Aliyev) samt ledere af store virksomheder, herunder $\mathrm{Na}$ tik Aliyev, der var chef for det største aserbajdsjanske benzinselskab AzPetrol og bror til Farhad Aliyev.

Hvorvidt de anholdte rent faktisk har været involveret i sådanne planer er svært at vide. Ali Insanov har efterfølgende indrømmet planerne, men forhørsmetoder og retssystem i Aserbajdsjan gør, at dette ikke nødvendigvis borger for sandheden.
Uanset om de tiltalte rent faktisk har haft planer af revolutionær art viser arrestationerne, at eliten ikke er så samlet, som den hidtil har fremstået, men samtidig at den nu styrende fraktion formentlig har vundet den interne magtkamp og sidder i en styrket position.

Der er forskellige tolkninger af, hvad der har adskilt de forskellige grupperinger. Disse tolkninger er dog ikke gensidigt udelukkende. Arrestationerne kan ses som Ilham Aliyev og hans nærmeste medarbejderes træk til at fjerne de økonomisk mest magtfulde medlemmer af eliten - hvortil blandt andre brødrene Aliyev og Insanov hørte - i stil med præsident Putins opgør med oligarkerne i Rusland. Derudover tilhører både Insanov og brødrene Aliyev andre klaner end den magtfulde Nakhichevan-klan, præsident Aliyev og de fleste medlemmer af eliten tilhører. Således har en gruppe af aserbajdsjanere, der oprindeligt stammer fra nu armensk-kontrollerede områder, oprettet en støttekomité for Ali Insanov, der tilhører denne gruppe.

Endelig kan konflikten ses som en sejr for hardlinerne blandt eliten over mere liberalt- $\varnothing$ konomisk indstillede medlemmer som Farhad Aliyev, der har forsøgt at reducere de høje toldsatser og øge frihandelen og dermed sat sig op imod indflydelsesrige personer, der tjener betydelige summer på kontrollen med et indbringende toldvæsen. 
Arrestationerne betød, at fokus i valgkampen flyttedes fra oppositionens demonstrationer til begivenhederne inden for styret, hvilket på forunderlig vis betød, at oppositionens opbakning svækkedes, og således blev de efterfølgende demonstrationer ikke nær så talstærke.

Samtidig betød arrestationerne, at op mod en fjerdedel af alle anmeldte kandidater trak sig af frygt for repressalier.

\section{Kontrolleret pres}

Myndighedernes reaktion på oppositionens krav såvel som den vestlige bevågenhed har fulgt en genkendelig strategi, som især Heidar Aliyev udviklede og mestrede til perfektion. Strategien består i på den ene side at fremstå som villig til at spille efter demokratiske spilleregler, men samtidig sørge for at have tilpas kontrol over valgkamp og valgets afvikling til at bevare magten.

Et eksempel er de ovenfor næunte forbud mod demonstrationer i det centrale Baku, samtidig med at man har understreget, at det ikke var et generelt forbud mod demonstrationer, men kun betinget af de ønskede lokaliteters nærhed til offentlige bygninger. Et andet eksempel er medierne, hvor man tillod oppositionen deres sikrede ret til gratis valgprogrammer på den offentlige fjernsynskanal, mens resten af den journalistiske dækning var præget af en stærk bias i forhold til det regerende
YAPs kandidater. Myndighederne har dermed understreget, at man ikke har brudt valgloven, men samtidig har den nødvendige neutrale politiske journalistik ikke været tilstede for befolkningen.

Denne bias gjorde sig ligeledes gældende på private fjernsynskanaler, der traditionen tro var loyale over for det siddende styre. Kun i den trykte presse kunne man finde oppositionsvenlige synspunkter, der blev præsenteret ligeså unøjagtigt og biased til fordel for oppositionen som det var tilfældet i de regeringsvenlige aviser til fordel for de siddende magthavere.

Derudover har det siddende styre enten kun modvilligt og sent eller helt nægtet at følge anbefalinger vedrørende valgloven fremsat af OSCE's Venice-kommission. Således tillod myndighederne, i form af et dekret fra præsident Ilham Aliyev blot en uge før valget, brug af blæk til mærkning af vælgere, der allerede havde stemt, hvilket gav store logistiske problemer og ifølge de fleste iagttagere gjorde indførslen ligegyldig og uden betydning. I samme dekret blev det tilladt NGO'er, der modtager mere end $30 \%$ af deres budget fra udenlandske kilder, at deltage som observatører, hvad der hidtil har været forbudt.

Dekretet indeholdt dog ikke indrømmelser i forhold til det vel nok vigtigste reformforslag fremsat af OSCE og andre udenlandske organisationer og diplomatiske repræ- 
sentationer, nemlig en ændring af sammensætningen af valgkommissioner, hvor der ved valget stadig var et flertal af repræsentanter for YAP samt uafhængige kandidater, der for langt størstedelens vedkommende er loyale over for det siddende styre. Her har det siddende styre fulgt Stalins gamle råd om at sikre sig kontrollen med optællingen.

\section{Magtdemonstrationer}

Det har været karakteristisk, at især Præsident Ilham Aliyev har forsøgt at distancere sig fra skylden i evt. valgfusk. Dels ved at udstede et dekret den 11. maj, i hvilket det pålagdes de lokale valgansvarlige at sørge for et frit og demokratisk valg efter forskrifterne i den aserbajdsjanske forfatning, dels ved det ovenfor omtalte dekret med revision af valgloven. Dermed bevarede styret muligheden for at fralægge sig ansvaret for et eventuelt ikke-demokratisk forløb af valghandlingen.

Derudover har der også været andre indrømmelser over for oppositionen, men dog nok primært til ære for det vestlige udland, i form af accepten af registreringen af to prominente eksil-oppositionsmedlemmer som kandidater. Ud over Rasul Guliyev drejede det sig om den første præsident i det selvstændige Aserbajdsjan, Ayaz Mutalibov. Det er imidlertid karakteristisk for den dobbeltsidede taktik, at ministeren for national sikkerhed samtidig med tilladelsen blev givet understregede, at de eksisterende arrestordrer på både Mutalibov og Guliev ikke ville blive ophævet på trods af deres registrering som kandidater, selvom valgloven sikrer kandidater ved parlamentsvalg immunitet.

Omvendt har myndighederne især i ét tilfælde udvist en så betydelig magtdemonstration, at der knap blev dækket over forsøget på at stække vigtige modspillere. Således blev lederen af ungdomsorganisationen Yeni Fikir (Ny Tænkning), Ruslan Bashirli i august anholdt for angiveligt at samarbejde med den armenske efterretningstjeneste, ligesom flere medlemmer af organisationen efterfølgende blev anholdt eller udelukket fra højere læreanstalter og andre truet med repressalier, hvis de skulle fortsætte deres politiske aktivitet. Man var muligvis bange for en gentagelse af ungdomsorganisationernes medvirken til regimeomvæltning som det sås i både Georgien og Ukraine.

Presset blev gjort tydeligt, da det at blive kaldt armensk spion er den værste beskyldning man som aserbajdsjansk politiker kan blive beskyldt for, og således var det også bemærkelsesværdigt, at der blev forsøgt at skabe sammenhæng mellem anholdelsen af Bashirli og lederen af Den Aserbajdsjanske Folkefront, Ali Kerimli, der ligeledes gennem sin kontakt med Bashirli skulle være indblandet i sagen.

Sagen viste, at myndighederne er 
villige til at bruge skrappe metoder for at bevare magten, men dog ynder at bruge mere fordækte metoder til opretholdelse af kontrollen med landet.

Der har fra udlandet lydt kritik under valgkampen. Hårdest i tonen var internationale NGO'er som $\mathrm{Hu}$ man Rights Watch, men den internationale valgobservatør mission (EIOM) har ligeledes kritiseret både mediernes rolle samt styrets begrænsning af ytring- og forsamlingsfriheden.

USA, der er den vigtigste vestlige politiske magt for Aserbajdsjan, kritiserede blandt andet politiets brug af vold mod demonstranter under valgkampen, men der har ikke været tegn på opmuntring til regimeomvæltning. Hertil er USA's strategiske interesser i landet formentlig for vigtige på trods af præsident Bush' erklærede mål om fremme af demokrati i verden. USA har således dels økonomiske interesser i form af olieleverancer fra især den snarligt færdigbyggede BTC-pipeline, dels militære interesser i form af to nyligt opførte radarstationer i hhv. det nordlige Aserbajdsjan tæt på grænsen til Rusland og i det sydlige Aserbajdsjan tæt på grænsen til Iran.

\section{Forudsigelig vinder}

I lyset af udviklingen i valgkampen var det derfor heller ikke den store overraskelse, at det foreløbige resultat, der blev offentliggjort dagen ef- ter valget den 7 . november, udråbte YAP til vinder med over halvdelen af pladserne i parlamentet, mens Azadlyq-blokken stod til bare 5 mandater.

Lige så lidt overraskende var det, at oppositionen - for nogles vedkommende allerede inden det foreløbige valgresultat blev offentliggjort - anklagede det siddende styre for valgsnyd og erklærede valgresultatet for en farce.

EIOM, der omfattede observatører fra OSCE, Europa-Parlamentet samt de parlamentariske forsamlinger fra Europarådet og NATO, erklærede i den foreløbige rapport, ligeledes offentliggjort den 7 . november, at valget ikke levede op til demokratiske standarder og kritiserede især stemmeoptællingen for at have været særdeles fejlagtig og præget af udbredt valgsvindel. Det amerikanske udenrigsministeriums talsmand, Adam Ereli, udtrykte opbakning til EIOM-rapporter og opfordrede til en undersøgelse af rapporterne om valgsvindel.

Præsident Aliyev og ledende YAPfolk, herunder generalsekretær Ali Ahmadov erklærede - ligeledes ikke overraskende - at valget havde været ovenud demokratisk, og kun i få tilfælde var der episoder mht. valgsvindel, der var nødvendige at undersøge nærmere. De blev bakket op af formanden for den centrale valgkommission, Mazahir Panahov. Som en mulig indrømmelse over for oppositionen og den vestlige kritik blev det lovet, at der ville blive 
iværksat undersøgelser af enkelte valgdistrikter, hvor der var forekommet rapporter om valgsvindel. Dette er dog så få distrikter, at uanset udfaldet af undersøgelserne vil det ikke rykke ved den overordnede magtfordeling i det nye parlament.

Som kuriosum kan det nævnes, at observatører udsendt fra SNG (der tæller lande som Usbekistan og Hviderusland, der ikke just er berømte for demokratiske valg) havde fundet, at valget levede op til demokratiske standarder. Det samme skete ved præsidentvalget i 2003! Så styret kan henvise hertil for bekræftelse af deres synspunkter.

Oppositionen afholdt den 9. november en stor demonstration $\mathrm{i}$ håbet om at omstøde resultatet og opnå nyvalg. Hvorvidt dette forehavende vil lykkes er på nuværende tidspunkt uvist, men præsidenten og regeringen bakket op af sikkerhedsstyrkerne virker meget opsatte på at forhindre nogen form for trussel mod deres magtpositioner.

\section{Fremtiden}

Det er endnu for tidligt at udelukke, at der kan ske regimeomvæltning, men forudsat at det officielle resultat står ved magt, og det nye parlament fremover vil have et flertal af YAP-repræsentanter og yderligere mange YAP-loyale uafhængige parlamentsmedlemmer, vil valget resultere i en stort set uændret situation i det aserbajdsjanske politiske landskab.
Styret har endnu engang styrket sin magtposition og svækket den nuværende opposition, der for en stor dels vedkommende har været involveret siden uafhængigheden. Vesten og især USA har ligeledes, i det mindste på kort sigt, sikret sig fortsættelsen af et samarbejdsvilligt styre i et strategisk område. Det kan dog vise sig, at man samtidig har skuffet især ungdommen ved ikke at have støttet de nye regeringskritiske ungdomsorganisationers krav om demokrati i højere grad end det er sket. Det er endnu for tidligt at sige, om denne generation vil vende deres fokus mod andre styreformer eller stadig vil se mod vesten for politiske systemer at kæmpe for.

Såfremt det skulle lykkes oppositionen at få succes med dens demonstrationer og få gennemført kravet om nyvalg er fremtiden mere åben, uden at det dog kan forventes, at et nyt og demokratisk Aserbajdsjan vil opstå fra den ene dag til den anden. Dertil er klantraditionen og korruptionen formentlig for udbredt og de demokratiske traditioner for svagt rodfæstede i det aserbajdsjanske samfund.

Jesper Weng Rasmussen er cand. scient. pol. fra Københavns Universitet. Han har studeret et år ved Khazar University i Baku, Aserbajdsjan og skrevet speciale om det politiske system $i$ Aserbajdsjan 